for this benefit. I can only send you a few brief particulars, communicated to me by the patient's mother, a poor washerwoman:

The patient, aged seventeen, became seized with epilepsy from fright six years ago.

The fits became gradually more and more frequent, and more and more severe, until about a year ago, when they recurred many times, indeed almost incessantly, every night, and frequently in the day, especially when the poor boy fell asleep, with blackness of the face, bitten tongue and bitten thumbs, convulsions, stupor, mania, idiocy.

On last Christmas day, and again on "Boxing day," it became necessary to put on the poor patient a strait waistcoat. It was next proposed to send him to a lunatic asylum. His fond mother, however, retained him at home, passing a great part of every night in watching him, and restraining him from convulsive and maniacal violence.

Two months ago, tracheotomy was ably performed by Mr. Holmes, of Vigo-street. The relief was almost immediate for a day or two the boy suffered from slighter fits; but from that time he has had no night fits, no "black" fits, no fit with bitten tongue and thumb, no convulsion, no loss of consciousness-nothing, in a word, except slight and transient faintishness !

His mind is restored from its idiocy, his physical health and strength are improved, and there is now, for the first time in his life, the question of some useful occupation for him!

The tube is worn without pain or inconvenience. It is kept free from mucus, being managed entirely by the patient's mother. The patient himself places his finger on its orifice whenever he wishes to speak.

The poor mother's joy is extreme, and her expressions of gratitude know no bounds; and I confess that my own reward in having, by the suggestion of tracheotomy in this special form of epilepsy, so far rescued a fellow-mortal from a state the most deplorable of mind and body, is of the highest kind.

I must add that the selection of the case for the operation by Dr. Ogle, who is paying special attention to the subject of epilepsy, was most judicious.

London, July, 1856.

\section{NERVES AND GANGLTA OF THE UTERUS.}

\section{To the Editor of THE LANCET.}

SIR,-Will you permit me to state in your journal, in the most positive terms, -

1. That no part of the neurilemma was removed from the ganglia and nerves of the unimpregnated and gravid uterus on any of the dissections described and delineated by me in the "Philosophical Transactions" for 1841 and 1842.

2. That no part of the neurilemma was removed from the ganglia and nerves of the heart in any of the dissections described by me, and delineated by Mr. West, in the "Philosophical Transactions" for 1849. For the accuracy of the drawings the artist has been held responsible; and when Mr. Lawrence and Mr. Owen compared the dissections and the drawings, they found a perfect correspondence between them, and recommended that they should be engraved and published in the "Philosophical Transactions," which was done. In the fourth of these engravings, ninety ganglia or ganglionic enlargements, or the nerves running over the anterior part of a heifer's heart, have been represented, and they are all perfectly visible to the naked eye in the preparation. The fifty cardiac ganglia, which from some mysterious cause were invisible to the referees in 1847, had become visible, and increased in number to ninety, in 1849 . There could therefore be no necessity for directing the artist to represent ganglia which did not exist; for, as Mr. Lawrence stated, there were more ganglia upon the heart than the artist had been able to delineate.

3. That in 1845 the Royal Medal in Physiology was illegally and fraudulently awarded to the anthor of a paper "On the Nerves of the Uterus," which contained a description and delineations of two specimens only, in which the ganglia and nerves had been wilfully mutilated by the removal of the neurilemma, which proceeding was carefully concealed till 1853 .

4. That in 1849 , four years after these proceedings, I published three memoirs "On the Ganglia and Nerves of the Uterus," which contained two engravings of the ganglia and nerves of the virgin uterus, with the following explanations of the plates:-

"Plate I. represents the left hypogastric and sacral nerves entering the hypogastric ganglion, and the bloodvessels, ganglia and nerves of the virgin uterus, a portion of the neurilemma being removed, and the size of the ganglia and nerves thereby greatly reduced below the natural size."

"Plate II. represents the right hypogastric nerve and ganglion, the ganglia and nerves of the same virgin uterus, with a great part of the neurilemma dissected off. The ganglia and nerves in the natural state are about four times the size here represented."

This proceeding in 1849 , which had been rendered necessary in consequence of what had been done in 1845 , and in a clan. destine manner, is now the only justitication, it appears, that can be given for the unprecedented and unwarrantable practice of removing the most important constituent tissue of the nervous structures of the uterus, the neurilemma, and practising gross deception upon the members of the whole medical pro. fession throughout the world.

It has now been demonstrated that the human unimpreg nated uterus possesses a great system of ganglia and nerves, which enlarges with the coats, bloodvessels, and absorbents during pregnancy, and which returns after parturition to its original condition before conception takes place.

It has likewise been demonstrated-

1. That the bloodvessels and the muscular structures of the auricles and ventricles of the heart are endowed with numerons ganglia and plexuses of nerves, which were first described by me and delineated in the "Philosophical Transactions" for 1849

2. That the nervous structures of the heart, which are dis. tributed over its surface to the apex and throughout its walls to the lining membrane and columnæ carneæ, enlarge with the natural growth of the heart before birth, during childhood and youth, until the heart has attained its full size in the adult.

3. That the ganglia and nerves of the heart enlarge like those of the gravid uterus when the walls of the ventricles are affected with hypertrophy.

4. That the ganglia and nerves which supply the left ven. tricle in the natural state are more than double the size of the ganglia and nerves of the right side of the heart.

These great nervous structures of the uterus and heart have existed as described in the "Philosophical Transactions" since the creation of the human race, and, if destroyed, the whole human race would speedily perish. These structures, on which the sensitive and contractile power of the uterus and heart depend, are beyond the reach of all envy and malice. The earth did not cease to roll round when Galileo was forced upon his knees to recant. The nervous structures of the uterus and heart remained when the Council of the Royal Society awarded the highest scientific honours for their destruction. "Nihil humanius quam labi, errare falli : nibil inhumanius quam errores fovere excrescera tueri." The consciousness of having stated the truth, and nothing but the truth, in the whole of this matter, will render it unnecessary to notice any assertions however untrue.

$$
\text { I am, Sir, your obedient servant, }
$$

Savile-row, July, 1856

$$
\text { R. LEE. }
$$

Postscript to a Paper "On the Canglia and Nerves of the Heart," by RoBert LeE, M.D., F.R.S., from the "Philosophical Transactions," Part I. for 1849.

"Since the communication above referred to was presented to the Royal Society, $I$ have made a very minute dissection in alcohol of the whole nervous system of the young heifer's heart. The distribution of the ganglia and nerves over the entire surface of the heart, and the relations of these structures to the bloodvessels and muscular substance, are far more fully displayed in these preparations than in any of my former dissec. tions. On the anterior surface there are distinctly visible to the naked eye ninety ganglia or ganglionic enlargements on the nerves, which pass obliquely across the arteries and the muscular fibres of the ventricles from their base to the apex These ganglionic enlargements are observed on the nerves, not only where they are crossing the arteries, but where they are ramifying on the muscular substance without the bloodvessels. On the posterior surface the principal branches of the coronary arteries plunge into the muscular substance of the heart near the base, and many nerves with ganglia accompany them throughout the walls to the lining membrane and columna carneæ. From the sudden disappearance of the chief branches of the coronary arteries on the posterior surface, the nervous structure distributed over a considerable portion of the left ventricle is completely isolated from the bloodvessels, and on these numerous ganglionic enlargements are likewise observed, but smaller in size than the chains of ganolia, formed over the bloodvessels on the anterior surface of the heart. In the 
accompanying beautiful drawings, Mr. West has depicted, with the greatest accuracy and minuteness, the whole nervous structures demonstrable in these preparations on the surface of the heart. But the ganglia and nerves represented in these drawings constitute only a small portion of the nervous system of the heart, numerous ganglia being formed in the walls of the heart, which no artist can represent. It can be clearly demonstrated that every artery distributed throughout the walls of the uterus and heart, and every muscular fasciculus of these organs, is supplied with nerves upon which ganglia are formed."

\section{POOR-LAW NEDICAL OFFICERS.} To the Editor of THE LaNOET.

SIR,-I shall feel obliged by your inserting this, and a copy of the letter I forwarded to the Poor-law Board on the 23rd instant, that your readers may understand how affairs are proceeding with the Union medical officers.

The forms sent with it are ruled in a similar manner to those now in use, but the lines are continued on the opposite sheet; so that at one glance the progress of the case may be seen for seven, eight, or ten weeks. In case any objection should be made to change the size of the present book, I have ruled one for the same covers, and it is headed as follows:-Name; Age; Residence; Nature of Disease; Week ending _ ; Necessaries ordered to be given to the Patient, or Obserrations, (the last two headings are repeated for seven weeks' entries;) Duration of each Case in Days; Distance in Miles from Surgeon's Residence; Termination of the Case, or carried on.

The three following forms are on paper which will make the book three and a half inches longer than the present one, and give to each patient a line of three feet in length, and is ruled for the following headings:-

Second Form.-No. of Case; Name; Age; Residence; Nature of Disease; Week ending___ Necessaries ordered to be given to the Patient; Observations, (the three last headings are repeated for seven weeks' entries;) Present State, or Termination of the Case.

Third Form.-No. of Case; Name; Age; Residence; Nature of Disease; Week ending - N Necessaries ordered to be given to the Patient, or Observations, (the two last headings are repeated for eight weeks' entries;) Duration of each Case in Days; Distance in Miles from Surgeon's Residence; Termination of the Case.

Fourth Form. - No. of Case; Name; Age; Residence; Nature of Disease; Week ending - - ; Necessaries ordered to be given to the Patient, or Observations, (the two last headings are repeated for ten weeks;) Termination of the Case.

It is possible that better forms might have been suggested, but I thought it desirable not to introduce greater change than absolutely necessary, fearing that if we ask too much, the Board would only "take it into consideration." I have every reason to believe that great good will accrue from our petitions to Parliament, as the numerous letters forwarded to me from the local secretaries convey the information that the various M.P.'s whom they have addressed, are perfectly astonished at the paltry sum we receive for our incessant labours, and promise their support next session, should the Poor-law Board persist in refusing adequate payment.

Two hundred and nine petitions have been presented to Parliament, and the same number of memorials to the Poor-law Board, and possibly also others without my knowing it. Those, however, represent upwards of one thousand men-a phalanx sufficiently powerful to effect much next session, should we be obliged again to appeal to the House of Commons; but I trust the three hundred and fifty-five Unions now on my list, and others also, will join in any future proceedings, and that no trivial objection to the mere wording of a petition will cause anyone to withhold his name from it, but that he will view it as a whole, and consider the general good only. Money is not in actual request at present, but I should certainly advise gentlemen to forward their subscriptions, in order that the Committee, with ample funds at command, may be in a position to pay current expenses, and at any moment to renew the contest. A majority of the Unions have not contributed their mite to the cause, many having signed the petitions without subscribing, and others the reverse. When I publish the list I hope this curious anomaly may be less apparent.

$$
\text { I am, Sir, yours \&c. }
$$

Royal-terrace, Weymonth, July, 1856. RiCHARD GrifFIN.
No. 22,030 .

12, Royal-terrace, Wey nouth,

My LoRDS AND GENTLEMEN,-I received a letter from your Honourable Board, June 20th, acknowledging the receipt of the memorial signed by one hundred medical men. In this letter you say - "As regards the request that the Board will, in order to lighten the burden of the arduous duties of medical officers, direct the alterations recommended to be made in the form of the weekly return, the Board have carefully considered the proposal, but are of opinion that the alterations suggested cannot properly be made, consistently with the due attainment of the object for which the return is required."

I have communicated this reply, through the medium of the medical journals, to all the Union surgeons, and am not surprised to find it has caused much regret, strengthening as it does the belief, openly expressed by many, that the grievances of the Union medical officers are little heeded by your Honourable Board. In this opinion, however, I cannot at present concur, believing the result of your deliberations has been arrived at by viewing the Amersham Weekly Return-sheet in its present form only, which was not intended by the memorialists, it being referred to simply as one that prevents the useless labour of rewriting the names weekly, and that any other having the same end would answer equally well. In quoting the Amersham Weekly Return-sheet, it was thought that no objection could possibly be offered, it having already been stamped by the approval of your Honourable Board for the last twenty years, which of course would not have been the case had it not satisfactorily carried out your policy in that district. I can now only account for its rejection by assuming that it is your determination to lay down a uniform system throughout the kingdom. With this view, I venture to submit four forms for your consideration, trusting one of them may be admitted into the extensive reform so much needed, and which we confidently hope you have in contem. plation. The weekly re-entry of the names is decidedly objectionable for all statistical purposes, and is proved to be a great hardship by the fact that not only has a memorial on the subject been presented to you by a large meeting of medical men assembled from all parts of the kingdom, but the prayer of it has been reiterated in other memorials from upwards of two hundred Unions, representing the opinions of from one thousand to fifteen hundred of your officers. I need scarcely add, that the adoption of any one of the forms now submitted to your notice will be a great saving to the nation, and contribute to the relief of the Union surgeons. I will not now refer to the other part of the memorial, as I trust before long I shall have the pleasure of hearing from you that your Honourable Board has decided to enforce a just and uniform system of payment throughout the kingdom, as the law empowers you to do, and thus prevent our body petitioning Parliament next session.

I have the honour to be, my Lords and Gentlemen, Your obedient servant,

To the Poor-law Board. Richard Griffin.

\section{CIVIL SURGEONS IN THE EAST. To the Editor of THE LANCET.}

SIR,-I regret that the civil surgeons of the Smyrna Hospital, in advocating their own claims, should have thought fit to disparage those of their brethren at Scutari. It was clearly no fault of the Smyrna surgeons that they had nothing to do. No doubt they would have been as glad to work as their brethren at Scutari; but there was some difference between the position of the two. If I am rightly informed, the Smyrna men had a sumptuous table and attendance, while the Scutari men had not even military rations for more than three months, for which they have received no compensation. Moreover the pay of five of the civil surgeons relieved from duty at Scutari on the 30 th of January* was not continued up to their arrival in England, contrary to all military rule, to common sense, and the treatment of every other branch of the service, surgeons of all other classes included. Also, the Scutari surgeons were promised local military rank, which was twice given and twice withdrawn without the least cause. The five surgeons alluded to were ordered to report themselves in London, and one of them lost an important engagement in Turkey in consequence. They have a clear claim for pay up to their arrival in London, and all the civil surgeons at Scutari are entitled to compensation for deprivation of rations for upwards of three months. 